\title{
Have the Aims of the Finnish Abortion Law Been Reached?
}

\author{
MARKETTA RITAMIES \\ Research Associate \\ The Population Research Institute of Väestöliitto \\ Helsinki, Finland
}

\begin{abstract}
The Finnish abortion law and its development is evaluated and the grounds and aims of the law are examined. The development of the abortion situation is described. On the basis of the above the author has reached the result that the Finnish abortion law has in many ways proven itself serviceable, the rate of abortions has reached such a low level that it is difficult to find a similar situation anywhere else in Europe. Illegal abortions have practically disappeared.
\end{abstract}

Keywords: induced abortion, law, Finland

Abortion has been a current issue in many countries. Especially in the USA, the right of women to an abortion has been the focus of much debate. In Europe abortion has been a topical question in Germany and Poland, for example.

In Finland, abortion has not been under much discussion for a long time. A new law was enacted in Finland in 1970, after a hectic debate, rendering women practically free abortion, and since then it has not been a matter of public debate. However, at the end of 1992 a discussion began in the press over the abortion law and demands were heard for restrictions to be made in the law.

Of course, opinions on abortion vary depending on the religious and moral background of the individual. Attitudes towards abortion are not only rational, but also emotional. However, the grounds for the legislation are medical, social and psychological facts and a relatively high consensus prevails over these.

In this article the present Finnish abortion law will be evaluated. First, the grounds and the aims of the law will be examined. Second, the article will focus on the extent to which the aims have been reached and if they still are meaningful twenty years after the characteristics of the law was enacted. Further, attention will also be drawn to how women who have obtained an abortion have changed since the enactment of the law, and which factors have possibly contributed to the current abortion situation in Finland - a situation better than in many other European countries. Statistics from the National Board of Health are used throughout this article, if not otherwise indicated. 


\section{Development of the abortion law}

\section{The 1950 law}

Finland's first abortion law came into being in 1950. The law was primarily intended to decrease illegal abortions and their health risks. Its purpose was also to define uniform criteria for evaluating abortions on medical grounds. According to this law an abortion could be granted on sociomedical and ethical grounds, as well as on medical grounds.

The objectives set for the law could not be realized very well during the two decades it existed. The number of illegal abortions did not decrease significantly. Nor, despite objectives to the contrary, was regional and social equality established. It was more difficult for those belonging to the lower classes to have an abortion, as it was for women living in rural and remote areas of the country. This was mostly due to the fact that the physicians who performed abortions were distributed unequally throughout the country (Härö and Koskela 1971, 1-14).

\section{The 1970 abortion law}

In the 1960 s there was growing dissatisfaction with the abortion law. Those critical of the law sought not only to further reduce the number of illegal abortions but also to establish the principles of women's freedom of choice and every child being a wanted child. Abortion was considered a measure to help an individual in the case of an unwanted pregnancy.

The current abortion law in Finland was passed on 1 June 1970 after a hectic debate. The main difference in the new law compared to the old one was in relation to social grounds. Under the new law, social grounds are sufficient grounds for abortion, whereas under the old they were taken into consideration only as additional factors. The new law is much broader than the previous one, but by no means does it render free abortion possible unless social grounds are interpreted very liberally.

According to the law, an abortion is granted to a woman requesting one, when:

1. pregnancy or childbirth would risk her life or health (medical grounds);

2. childbirth and child care would be a considerable strain on her and her family economically and socially (social grounds);

3. she is pregnant against her will (ethical grounds);

4. she was not yet seventeen years of age or was over forty or already had four children at the moment of conception (age and childbirth limitations);

5. there is reason to expect the child to be mentally retarded or to have a difficult illness or physical defect (eugenic grounds);

6. illness, disturbed psychological functioning or a comparable factor seriously limits the capacity of one or both parents to take care of the child (limited capacity to take care of the child).

The law forbids abortion after the 16th week of pregnancy, except on medical grounds, in which case there is no limitation. However, the National Board of Health has the right to give permission for an abortion on special grounds, not, however, after the 20th week of pregnancy. In 1979 a restriction was added to the law according to which an abortion induced on social grounds must be performed during the first 12 weeks of pregnancy instead of the first 16 weeks, as it was previously. Since 1985 the National Board of Health has had the right to grant permission for an abortion up to the end of the 24 th week, when it can be presumed that the child will be mentally 
retarded or that the child would have a difficult illness or physical defect. (Lahti 1985, 1809-1814).

According to the prevailing law, an abortion is induced by a physician on the basis of a statement given by another physician. An abortion may be performed on medical grounds during any period of gestation, and on social and ethical grounds and on grounds of limited capacity to take care of the child up to the end of the 12 th week of pregnancy.

With the permission of one physician, the performing physician, abortion can be induced up to the end of the 12 th week of pregnancy, if the woman was under 17 years of age, over 40 or already had four children at the time of conception.

The National Board of Health may grant permission for an abortion up to the end of the 24th week of pregnancy, when there is reason to presume that the child would be mentally retarded or that the child would have a serious illness or physical defect. The Board may also give permission up to the end of the 20th week of pregnancy when the woman was under 17 years of age at the time of conception or other special reasons exist. (Since December 1, 1992 the permissions are granted by the National Board of Medicolegal Affairs.)

\section{The development of the abortion situation}

The abortion law of 1970 which permits abortion on social grounds has already been in force for twenty years. Before, abortions were performed on medical grounds, now, on social grounds.

While in 1969 , a year before the new law, $60 \%$ of abortions were performed on medical grounds, soon after the law was enacted, abortions were made to a great extent to social grounds. In 1975 merely six percent of abortions were performed on medical grounds and at present the proportion is less than one percent. In 199184 percent of those having an abortion did so on social grounds.

Now when the law has been in force for such a long time, it can clearly be seen how this law has succeeded in fulfilling its targets: to reduce the number of abortions, to eliminate illegal abortions and their health risks and to give women living in different parts of the country equal rights to abortion. Further, one can also state that free abortion is not used as contraception.

\section{The number of abortions}

As the 1970 abortion law came into force, many were afraid that the number of abortions would grow significantly. In the beginning it seemed that this fear would come true. The number of legal abortions increased rapidly. In 197323,000 abortions were performed. However, after that the number of abortions started to decrease year by year. In 1991 only 11,700 abortions were induced in Finland. While there were 22.4 abortions per 1,000 women aged 15-44 in the peak year 1973, the number was only 10.7 in 1991 (Figure 1). Correspondingly, the number of abortions per 100 live births went down from 41.1 to 17.8 . Hence, one of the purposes of the law, to reduce the number of abortions, has been attained.

\section{Illegal abortions}

During the first few years after the enforcement of the 1970 law, the strong increase in abortions meant mainly that illegal abortions could be performed legally. According to the estimates, the number of illegal abortions in the $1950 \mathrm{~s}$ and $1960 \mathrm{~s}$ varied 
Fig u re 1. Abortions per 1,000 women aged 15-44.

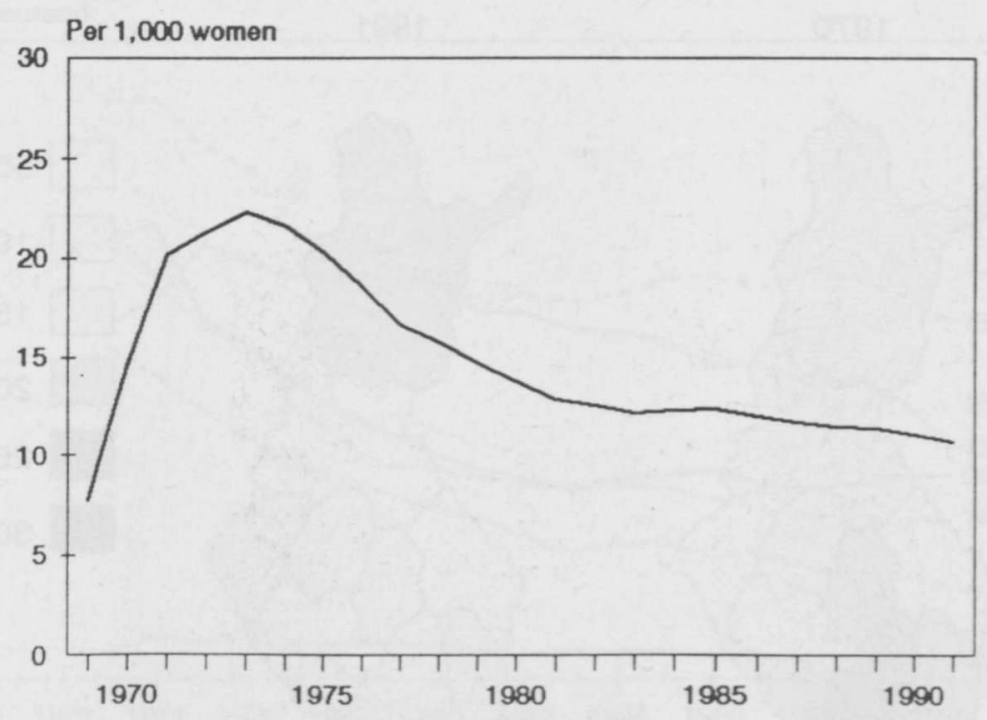

between 18,000 and 25,000 annually. Under the present law, they have gradually disappeared almost totally. Virtually all abortions in Finland are legal. The annual number of illegal abortions treated in hospitals is only a few dozen, but even altogether hardly more than one or two hundred illegal abortions are induced annually.

\section{Repeat abortions}

The new law has not made abortion into a contraceptive. The majority of the annually induced abortions are still first abortions. In 1991 for $71 \%$ of the women having an abortion, this was their first, for $21 \%$ their second and for only five percent their third or more.

The low total abortion rate also indicates the small amount of repeat abortions. In Finland the total number of abortions performed during a woman's fertile period was 0.4 in 1990. In Denmark the corresponding figure was 0.5 and in Sweden 0.6 (Yearbook of Nordic Statistics 1974-1990). In many former socialistic countries, however, abortion was almost the only contraceptive method used and, for example, in some parts of the former Soviet Union, 5-7 pregnancies were interrupted during a woman's fertile period of life.

\section{Gestation}

It has been indicated in the abortion law that the abortion has to be performed as early as possible. This aim has been realized to a great extent under the existing law, because the proportion of early abortion has grown substantially. The year before the present abortion law was enacted, in 1969, 53 percent of abortions were performed before the pregnancy had lasted 12 weeks. In 1991 the same proportion was 94 percent. 
Fig u re 2. Abortions per 1,000 births by provinces in 1970 and 1991.

1970

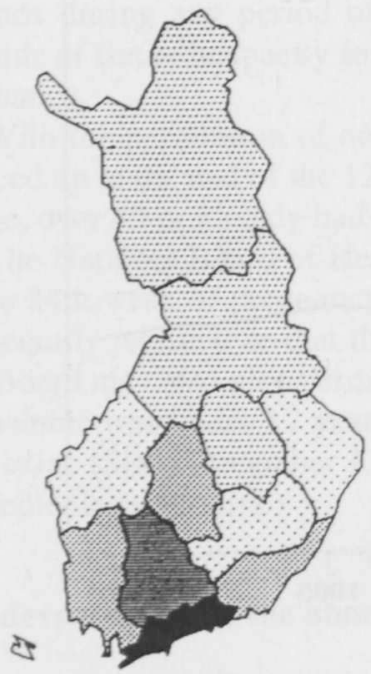

1991

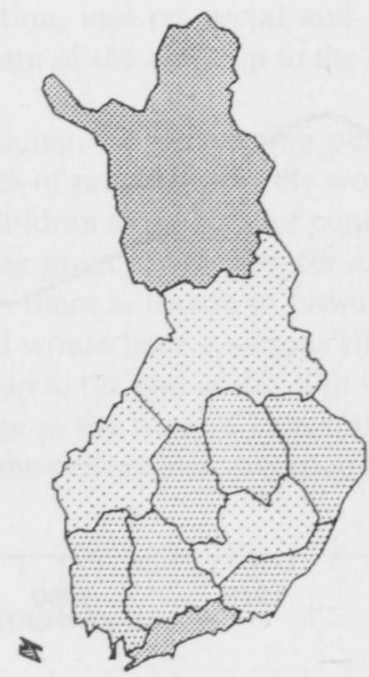

$50-100$

101-150

$151-200$

201-250

$251-300$

$301-350$

\section{Regional differences in abortions}

Before the 1970 law, fewer abortions were induced in those parts of the country where the general standard of living and state of health were the poorest. This was partly due to the fact that physicians rendering the required statement for the abortion were unevenly located in the different parts of the country and partly due to their attitudes. In pronouncing their statements the physicians were not always fair and consistent.

Under the new law the great differences in abortions between the various parts of the country have clearly narrowed. In 1970 when the present law came into force, two or three times as many abortions per 1000 births were performed in the southern parts of the country compared with other parts, while in 1991 the number of abortions performed in the southernmost province of Uusimaa did not much differ from the number of abortions in most other provinces. The diagonal zone with a low number of abortions in the central part of Finland seen in Figure 2 is probably connected above all with the revivalist movements active in these areas.

\section{Characteristics of those having an abortion}

Under the new abortion law, the characteristics of women having an abortion have changed significantly, e.g. with regard to age, marital status, social group and number of children.

Age

Under the old abortion law, many abortions were performed on older women. Under the current law all age groups up to $45-49$ showed at first an increase in abor- 
Figure 3. Age-specific abortion rates.

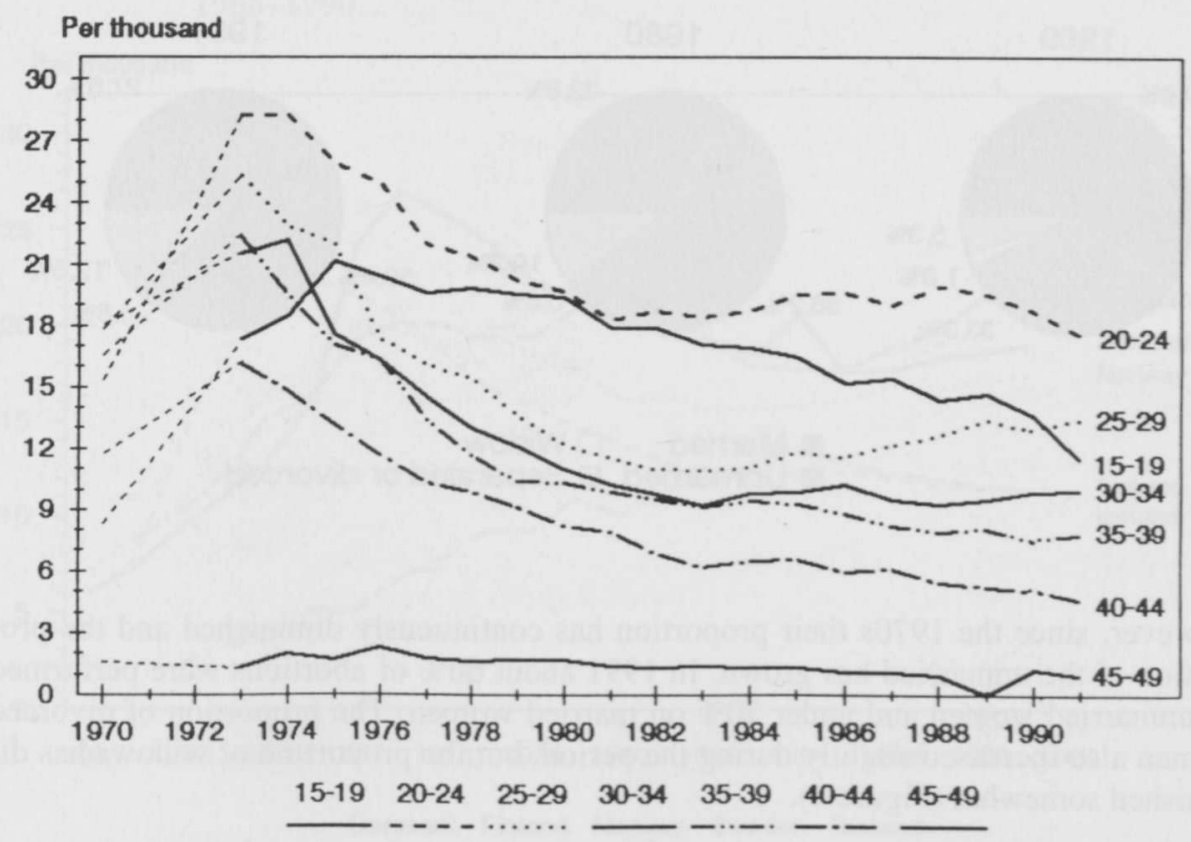

Age-specific abortion rates 1971 and 1972 are lacking

tions, but this was soon followed by a decrease. The decrease was most significant in relation to older age groups, least significant in relation to the youngest women, those aged 15-19 (Figure 3).

Age-specific abortion rates started to decrease from 1973 on in age groups older than 25. The number of abortions grew in the beginning among the youngest, aged 15-19. In 1973, when the abortion rate was highest, $15 \%$ of abortions were performed on women under 20 years of age. The proportion of adolescent abortion was at its highest in 1980. At that time $24 \%$ of abortions were induced in women under 20 years of age. After this the proportion of the young started to decrease and in 1991 was not more than $15 \%$. Twenty-five percent of the abortions were on women aged 20-24 and 21 percent on women aged $25-29$. In other words 60 percent of the abortions were induced in women under 30 years.

The abortion rate among the youngest, women under 20 years of age, has developed positively in the $1980 \mathrm{~s}$, and is the result of an effective information on contraceptive methods. The young today are very aware of contraceptive methods. This is also reflected in their behavior. In the 1960s about one-half of the young did not use contraceptives during their first sexual intercourse, while the corresponding figure in the beginning of the 1990s was one-fourth (Maunula 1992). An open question is, however, why the abortion rate has not changed as positively among those aged 20-34 years as among the young.

\section{Marital status}

The fact that the age structure of those who have had an abortion has become younger naturally relates to the fact that the proportion of unmarried among them has increased. Before 1970 most of the legal abortions were performed on married women. 
Fig u r e 4. Legal abortions according to marital status in 1969, 1980 and 1991.
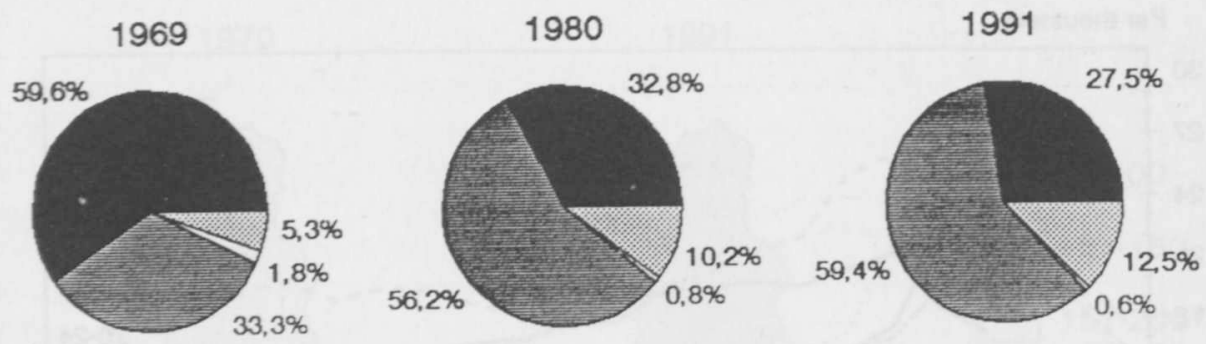

\section{$\begin{array}{ll}\text { - Married } & \square \text { Widow } \\ \text { - Unmarried } & \text { Separated or divorced }\end{array}$}

However, since the 1970 s their proportion has continuously diminished and the proportion of the unmarried has grown. In 1991 about $60 \%$ of abortions were performed on unmarried women and under $30 \%$ on married women. The proportion of divorced women also increased slightly during the period, but the proportion of widows has diminished somewhat (Figure 4).

\section{Number of children}

Before the current abortion law, almost $70 \%$ of the women having an abortion had had children before, almost one-third at least four. Fertility was high and abortions were presumably induced both for health reasons and for birth control. As fertility decreased during the new law and abortions among older women decreased, the number of abortions among women without children increased. Half of the women who had an abortion in 1991 had not yet given birth. Less than a fifth had had one child and one-fifth two children.

\section{Social class}

In the 1950 s and 1960 s women belonging to the lowest social class had more difficulties obtaining an abortion than those in the highest and middle class. Under the present law, due to more common and equal grounds for abortion, the differences between the social classes have been leveled out. The proportion of abortions has clearly increased within the lowest social class and decreased within the highest (Härö et al. 1976, 34). The data on social groups are based on an old classification and therefore it is difficult to get reliable information on the current situation. Abortions are clearly performed mainly on women belonging to the lowest social groups. For example in a study on primiparae in Northern Finland in the mid-1980s it was found out that women in the lowest social groups resorted to abortion more often than those in the higher social groups (Juntunen, K. et al 1983, 3-9).

\section{The Finnish abortion law is still serviceable}

During the two decades the abortion law has been in force, the law has in many ways proven itself serviceable. The rate of abortions has reached such a low level that 
Fig u r e 5. Abortions per 1,000 women aged 15-44 years in the Nordic countries, 1968-1990.

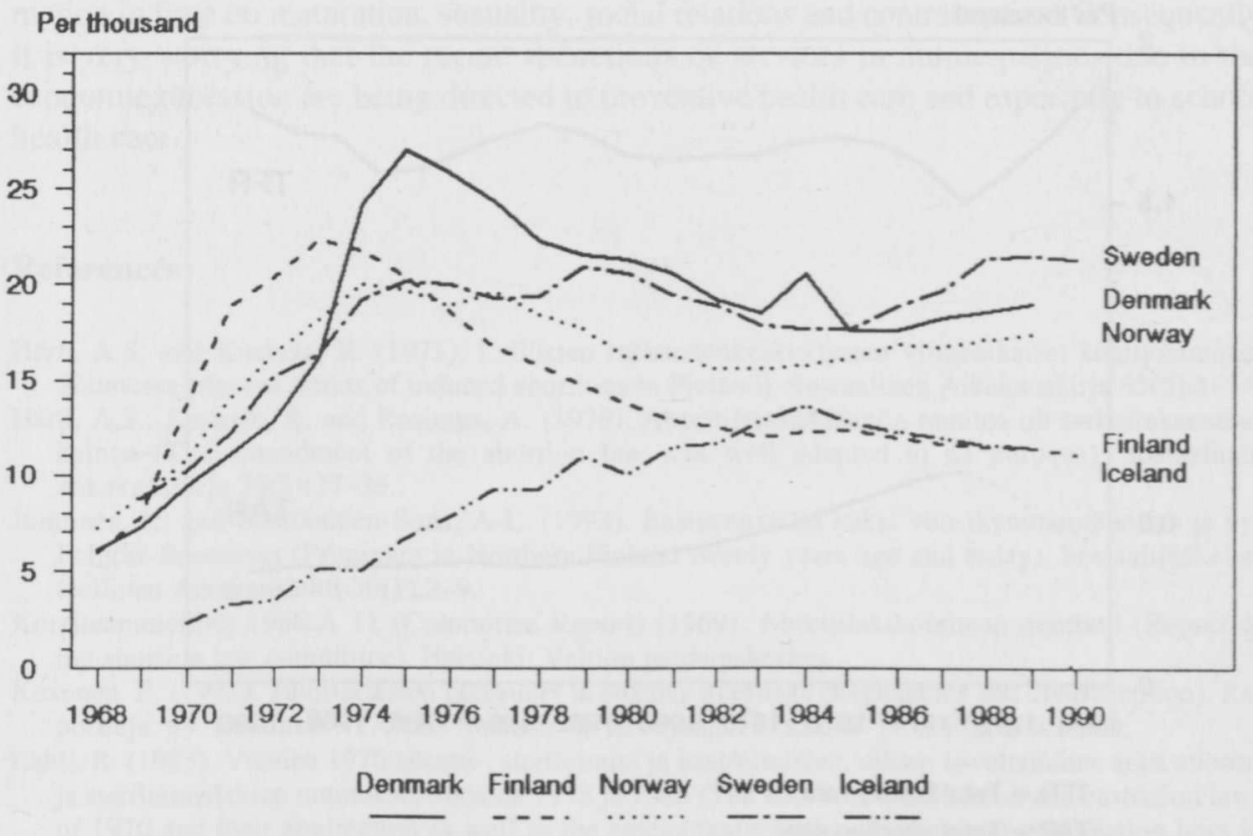

it is difficult to find a similar situation anywhere else in Europe. Although abortion policy has been similar since the mid-1970s in all the Nordic countries, Finland has the lowest abortion rate with the exception of Iceland (Figure 5).

Illegal abortions have practically disappeared. Women living in different parts of the country and in different population groups now have equal access to abortion services. Abortions are also performed in the early phase of pregnancy before the end of the 12 th week of pregnancy. Abortion has not become a birth control method.

Although the normal time limit for an abortion was shortened in 1979 from the 16 th week of pregnancy to the 12 th week, this did not mean any restriction in the liberal abortion law. It was rather an attempt to increase the proportion of early abortions with the objective of lessening the health and other risks involved. When the current law was being drawn up, the 12 -week limit was already being considered. But the level of knowledge and the physician and hospital situation were not considered to be good enough in the remote areas of the country to allow for the 12 -week limit. Eight years later the situation in relation to sex education was thought to have improved enough to allow for a shorter time limit. In addition, shortening the time limit was seen in the context of the government taking steps to improve the effectiveness of contraceptive education and making contraceptives more available. (Lahti 1985, 1809-1814).

In Finland knowledge about the use of contraceptives is rather good at present. The family planning services available in health care centers are well-organized and different kinds of birth control methods are at the disposal of those who want to use them. The school health care system is also well-organized. Contraceptive education is thus given to young people by qualified health professionals rather than by the teacher, usually a domestic science teacher, assigned to the task. Sex education in schools started later than in the other Nordic countries and depended on the teacher's interest and varied in different parts of the country. 
Fig u re 6. Total fertility and abortion rates, 1970-1990.

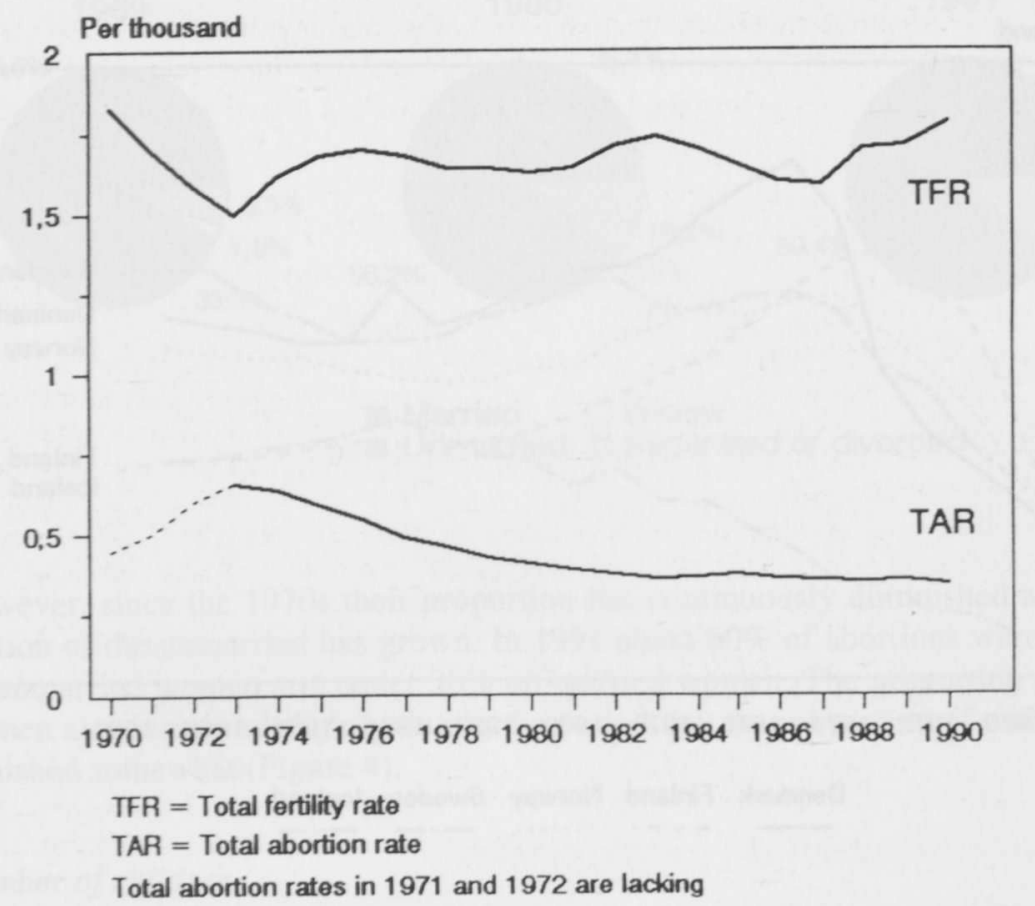

Satisfaction with the present abortion law is widespread and the rationale behind the law, as well as the goals set by it, are still considered to be acceptable. Now and then the abortion question emerges in the press on the initiative of some private person or group or organization.

Sometimes the low fertility of Finland has been of concern to people who feel that a decrease in the number of abortions would result in rising fertility. When the number of abortions was highest in Finland in 1973, fertility was at its lowest. Evidently the modification of the abortion law led to more careless contraception for some time. When it was possible to prevent an unwanted pregnancy legally, contraception was neglected. When contraceptive methods gradually became more reliable, they came to be preferred as a means of birth control. Abortion rates have decreased continually, although fertility has been wavelike and clearly below the replacement level (Figure 6). In Finland no connection can be seen between abortions and fertility.

\section{Future prospects}

No major changes in the abortion law are likely in the near future. However, there is still a lot to do to prevent abortions which are performed due to lack of information and poor availability of birth control methods. There is also reason to pay more attention to those social and psychological factors which make having a child or taking care of it a considerable strain on a woman and therefore are seen as justifying an abortion.

During the coming years, attempts should be made to ensure that all those having an abortion be in an equal position. Actual practice in relation to defining social indications and the special reasons for acquiring a late abortion should be rationalized. 
The abortion policy has been successful in Finland. Still, emphasis should be on the prevention of pregnancies. Every new age class ought to be given relevant information in time on maturation, sexuality, social relations and contraception. Consequently it is very worrying that the recent reductions of services in municipalities due to the economic recession are being directed to preventive health care and especially to school health care.

\section{References}

Härö, A.S. and Koskela, R. (1971). Laillisten raskaudenkeskeytysten viimeaikaiset kehityssuunnat Suomessa (Recent trends of induced abortions in Finland). Sosiaalinen Aikakauskirja 65(5):1-14.

Härö, A.S., Koskela, R. and Rasimus, A. (1976). Aborttilainsäädännön muutos oli tarkoituksenmukainen (The amendment of the abortion law was well adapted to its purpose). Sosiaalinen Aikakauskirja 70(5):27-36.

Juntunen, K. and Hartikainen-Sorri, A-L. (1993). Ensisynnyttäjä kaksi vuosikymmentä sitten ja nyt Pohjois-Suomessa (Primipara in Northern Finland twenty years ago and today). Sosiaalilääketieteellinen Aikakauslehti 30(1):3-9.

Komiteanmietintö 1968:A 11 (Committee Report) (1969). Aborttilakikomitean mietintö (Report of the abortion law committee). Helsinki: Valtion painatuskeskus.

Kosunen, E. (1993). Teini-ikäisten raskaudet ja ehkäisy (Teenage pregnancies and contraception). Raportteja, 99. Helsinki: STAKES Sosiaali- ja terveysalan tutkimus- ja kehittämiskeskus.

Lahti, R. (1985). Vuoden 1970 abortti-, steriloimis- ja kastroimislait, niiden soveltaminen sekä aborttija steriloimislakien muutokset vuosina 1978 ja 1985 (The abortion, sterilization and castration laws of 1970 and their application as well as the amendments in the abortion and sterilization laws in 1978 and 1985). Suomen Lääkärilehti 40(18):1809-1814.

Maunula, M. (1992). Nuoret ja kondomi (The young and the condom). Helsinki: Väestöliitto, Väestöntutkimuslaitos.

OSF (Official Statistics of Finland) (1973-1989) Health Services 1971-1987. Helsinki: National Board of Health in Finland.

OSF (Official Statistics of Finland) (1970-1991). Vital Statistics 1968-1988. Helsinki: Central Statistical Office of Finland.

OSF (Official Statistics of Finland) (1970-1974). Public Health and Medical Care 1968-1970, XI:7173. Helsinki: National Board of Health.

OSF (Offical Statistics of Finland) (1993). Raskauden keskeytykset vuoteen 1991 Suomessa (Induced abortions in Finland until 1991). Health 1993:3. Helsinki: STAKES Sosiaali- ja terveysalan tutkimus- ja kehittämiskeskus.

Yearbook of Nordic Statistics 1973-1990 (1974-1991). Stockholm and Copenhagen: The Nordic Council and Nordic Statistical Secretariat. 